$\left.\begin{array}{c}\text { LOCAL WISDOM, } 11 \text { (2): 75-89, } 2019 \\ \text { Local Wisdom Scientific Online Journal } \\ \text { ISSN: 2086-3764 }\end{array}\right) \begin{array}{r}\text { WISDOM } \\ \mathrm{w}\end{array}$

\title{
Typology and Morphology The Building in the Area of Gunung- Gunung Street Malang City
}

(Case Study: Buildings on Jl. Arjuno no. 36, Jl. Tanggamus no. 23, Jl. Tenes no 14, Jl. Wilis

Nur Ratih R. ${ }^{*}$

no. 27 , Jl. Rinjani no 17, dan Jl. Buring no. 2)

1. Magister Architecture, University of Brawijaya, Malang, Indonesia

Corresponding Author: nur.ratiih@gmail.com

Keywords: typology, colonial architecture, building facade

Kata Kunci: tipologi, arsitektur kolonial, fasad bangunan

\begin{abstract}
Bergenbuurt area in Malang city has cultural heritage such as ancient buildings that have a colonial architectural style with the distinctive facade. Malang City Government itself has set this area as an area of cultural heritage so the existence, identity and image of the area could be maintained. This study is an advanced study of Antariksa et al (2004) conducted at the study area with a focus on the preservation of the buildings. The study showed some buildings that are considered to have the authenticity of a unique design and create the character of the area. This advanced study aims to identify the typology and morphology of the building that has been considered by previous researchers can create/influence the character / visual quality of the area. This study used a qualitative approach with descriptive methods of data analysis. Primary data obtained by field surveys on buildings based on the results of previous research. Building condition data from previous research is secondary data that is used to conduct study morphology of the building. Results of this study are expected to provide direction development of the area to preserve the visual character of the area.
\end{abstract}

Abstrak

Kawasan jalan gunung-gunung atau biasa disebut dengan kawasan Bergenbuurt di Kota Malang menyimpan peninggalan sejarah berupa bangunan-bangunan kuno yang memiliki gaya arsitektur kolonial dengan fasad yang khas. Pemerintah Kota Malang sendiri telah menetapkan kawasan ini sebagai kawasan cagar budaya agar keberadaan, identitas dan citra kawasan ini tetap terjaga. Kajian ini merupakan kajian lanjutan dari Antariksa dkk (2004) yang dilakukan pada lokasi jalan gunung-gunung tentang pelestarian bangunan. Kajian tersebut memunculkan beberapa bangunan yang dinilai memiliki keaslian rancangan yang unik dan menjadi pembentuk karakter kawasan. Kajian lanjutan ini bertujuan untuk mengidentifikasi tipologi dan morfologi bangunan yang telah dinilai dapat membentuk/ mempengaruhi karakter/ kualitas visual kawasan menurut peneliti terdahulu. Kajian ini menggunakan pendekatan kualitatif dengan metode analisis data secara deskriptif eksploratif. Data primer diperoleh dengan melakukan survei lapangan pada bangunan-bangunan berdasarkan hasil penelitian terdahulu. Data kondisi bangunan dari penelitian terdahulu merupakan data sekunder yang digunakan untuk melakukan kajian morfologi bangunan. Hasil kajian ini diharapkan dapat memunculkan arahan pengembangan kawasan guna melestarikan karakter visual kawasan.

@ 2017 The Authors. Published by GKAK UNMER Malang

*Corresponding Author: nur.ratiih@gmail.com 


\section{Introduction}

The Gunung-Gunung Street (Burgenbuurt) area in Malang City has a unique characteristic in terms of its architecture. This area holds many historic buildings in the form of ancient houses in colonial style. Based on the Decree of the Mayor of Malang District Head Number SK / 104 / U / II / ' 80 , it is explained that the housing environment that needs to be preserved is Jl. Ijen, Jl. Semeru, Jl. Bromo, Jl. Arjuno, Jl. Tangkubanperahu, Jl. Tennes, Jl. Sumbing, Jl. Sindoro, Jl. Slamet Park, Jl. Welirang, Jl. Buring, Jl. Lawu, Jl. Argopuro, Jl. Lamongan, Jl. Merapi, Jl. Muria, Jl. Cerme, Jl. Ungaran, Jl. Baluran, Jl. Guntur, Jl. Anjasmoro, Jl. Raung, Jl. Simpang Balapan, Jl. Merbabu, Jl. Tampomas, Jl. Lasem, Jl.Ringgit, Jl. Papandayan, Jl. Cikurai, Jl. Jakarta, Jl. Pahlawan Trip, Jl. Rinjani, Jl. Dempo, Jl. Kerinci, Jl. Tanggamus, Jl. Retawu, Jl. Wilis, Jl. Panderman, Jl. Telomoyo, Jl. Pandan, Jl. Kawi, Jl. Gede and its surroundings. The decree was strengthened to be Regional Regulation Number 5 of 1986, then changes were to be Regional Regulations Number 10 of 1989 and the latest was the Regional Regulation of Malang City Number 4 of 2011 concerning the 2010-2030 RTRW.

According (Antariksa, Rusdi Tjahjono, 2004), the architecture of buildings in the study area is dominated by colonial architecture types from 1915-1930, namely buildings that have adopted tropical buildings with pointed roofs, cantilevers, terraces, and ornaments on openings. This study is a follow-up study from Antariksa et al. Which was conducted on the location of Gunung-Gunung street on building preservation. The study gave rise to several buildings which were considered to have unique design authenticity and became the shape of the regional character. This follow-up study aims to identify the typology and morphology of buildings that have been assessed to be able to shape /influence the character / visual quality of the area according to previous researchers.

\section{Purpose}

This study is written with the aim of:

1. Identify the typology and morphology of buildings on gunung-gunung Street that are considered to shape the character / visual quality of the area.

2. Provide recommendations for regional development in order to preserve the quality and visual character of the region.

\section{Method}

This study uses a qualitative approach with descriptive exploratory data analysis methods. Qualitative research produces descriptive data that occurs in the object of study with the main purpose of systematically describing the facts and object characteristics of the study.

This study began with a search of previous research conducted at the study location. Previous research which is the reference in this study is research from (Antariksa, Rusdi Tjahjono, 2004) entitled "Preservation and Protection of Ancient-Historic Buildings in Jalan Gunung-Gunung Malang City". The study gave several buildings that were considered to have unique design authenticity and became the shape of the regional character.

Data collection was conducted to obtain primary and secondary data in this study. Primary data is obtained by conducting a field survey of buildings that are considered to have a unique design authenticity and become a regional character builder by previous researchers, namely a building on Jl. Arjuno no. 36, Jl. Tanggamus no. 23, Jl. Tenes no 14, Jl. Wilis no. 27, Jl. Rinjani no. 17, and Jl. Buring no. 2. The data is used to analyze building typology. Secondary data from previous studies were used to see the condition of these buildings in 2004 for morphological analysis by seeing the changes that occurred in 2015. Analysis of the data was carried out using descriptive methods. 


\section{Literature review}

\section{Typology in Architecture}

Etymologically, typology comes from two Greek words, namely: typos which mean type and logos which means science / scientific field. Literally, typology can be interpreted as the study of everything related to type. Loekito (1994) in (Antariksa, 2010), defines typology as a concept that sorts a objects group based on the character's similarity in their basic forms. Whereas Sulistijowati in (Ramadanta, 2010) defines typology as an act of thinking in terms of grouping3. Basically, typology is a concept that describes object groups on the basis of the similarity of the basic characteristics with certain rules. According to Sulistijowati in (Ramadanta, 2010), the rules used in typologies include:

1. Functions (covering space, structural, symbolic, etc.);

2. Geometric (includes form, order principle, etc.); and

3. Style (covering period, location or geography, politics or power, ethnicity and culture, etc.).

\section{Morphology in Architecture}

Morphology comes from the word morphology, which means the science of form. According to Schulz (1988) in, (Syahrozi, 2013), morphology concerns spatial figural quality and the context of the form forming space that can be divided through patterns, hierarchies and spatial relationships with one another.

According to Ronald (2008) in (Setyabudi, Antariksa, \& Murti Nugroho, 2012), it is said that morphology is the study of changes in the shape, relationship, metamorphosis and structure of an object. In morphology, shape changes usually through a process of evolution or modification with quite a long time 6. Whereas (Syahrozi, 2013) 7 states that the study of morphology does not only see the physical shape's changes in that occur but more important is the recording of a series the change processes and reasons or meanings underlying the change. This change can describe a change in ideas or meanings in history. Changes that occur can be caused due to various reasons, such as:

1. Dimensions change,

2. Cutting or enlargement,

3. Space addition or form,

4. Colour changes and arrangement

5. Changes caused by the use of material that is different from the original state.

\section{Building Facades Overview}

The easiest part of the building and architecture to see is the building face or better known as the building facade. The building facade is also often called the look, the outer shell or the appearance of the building because the building facade most often has given an assessment by observers without first checking the entire building both the entire outer side, as well as the inside of the building. The assessment was not only carried out by architects but also ordinary people (Prijotomo in Ramadanta, 2010) 8. The facade composition, with considering the functional requirements (windows, doors, sun shading, roofing) is done by creating harmonious unity using proportional composition, structured, material, colour and decorative elements principally. Another thing that is important to get more attention is the openings proportion, building height, the principle of repetition, the good composition balance, and the themes included in variation9. According to Lippsmeier building facade elements which also components that affect the building facade are 10: 
1. Roof;

2. Walls; and

3. Floor.

\section{Overview of Colonial Building Style}

1. Colonial residential buildings style from the 1851-1880 era.

The era of 1851-1880 was the era of colonial buildings Style Indisch Empire and Voor Style 1900. These styles have characteristics namely, the building has a large yard, a roof shape shield, impressed monumental, wall paint from white limestone, and develop into a building which is more responsive to the tropical climate with the presence of luifel (eaves) from corrugated zinc and also the use of new materials, iron.

\section{Colonial of residential buildings style from 1881-1910 era.}

The era of 1881-1910 was an era that was greatly influenced by the flow of European Romanticism and buildings with Romantiek Style that were many uses of ornaments, both on the room, and on the faces of buildings. Colonial residential buildings in the era of 1881-1910 dominantly influenced by several styles, including the Voor Style 1900, many with decorative elements on the face of the building.

3. Colonial of residential buildings style from the 1911-1942 era.

The building styles development in this era reached its peak in 1915, but there are still many elements from the previous era building which used as face elements of buildings in this era, such as the use of gable / gevel, types, materials, and ornaments of the previous era. Then what stands out in this era is the traditional roof formation, which shows the acculturation of colonial culture with the local culture.

\section{Discussion}

The Bergenbuurt area (Bouwplan V) is a residential area built by the Dutch colonial government in 1924/1925. The purpose of its development is as a residence for European groups in Malang, which at that time showed rapid growth. The implementation is directed to the western part of the city, because the geographical conditions of the land are relatively high and to prevent the development of the city increasingly away from the city centre.

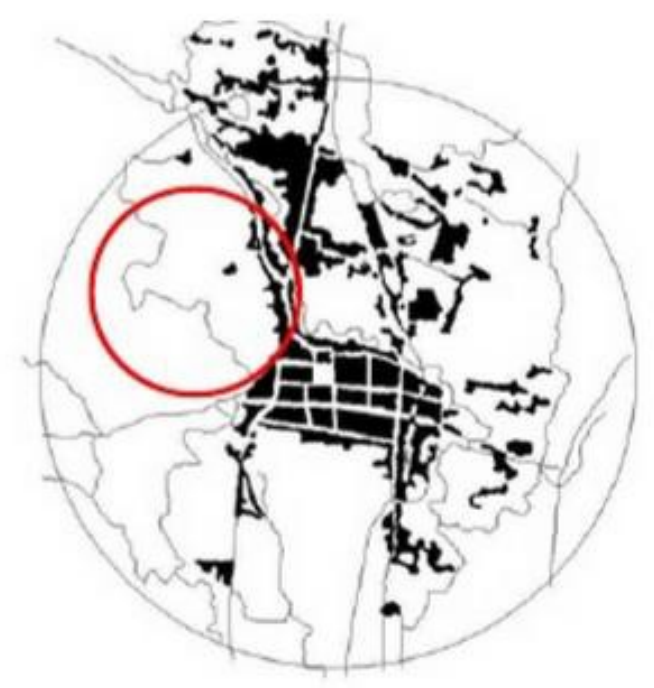

Figure 1. Bouwplan V Development Area (Source: Handinoto, 1996) 
Because it was developed during the Dutch rule, the architectural forms that existed in the Bergenbuurt region showed a distinctive visual character in the form of a colonial style building. According to Antariksa et al, there are several buildings that show the authenticity of a unique design and form the character of the region, including buildings on Jl. Arjuno no. 36, Jl. Tanggamus no. 23, Jl. Tenes no 14, Jl. Wilis no. 27, Jl. Rinjani no. 17, and Jl. Buring no. 2.

\section{The building of Jl. Arjuno no.36}

Building on Jl. Arjuno no 36 is located on the corner of a junction between Arjuno street and Semeru street Malang. Corner land has two facades/building facades. In this building, the facade of the building is oriented west and north. Based on secondary data obtained, this building has a function as a residence. Photos of buildings in 2004 can be seen in Figure 2.

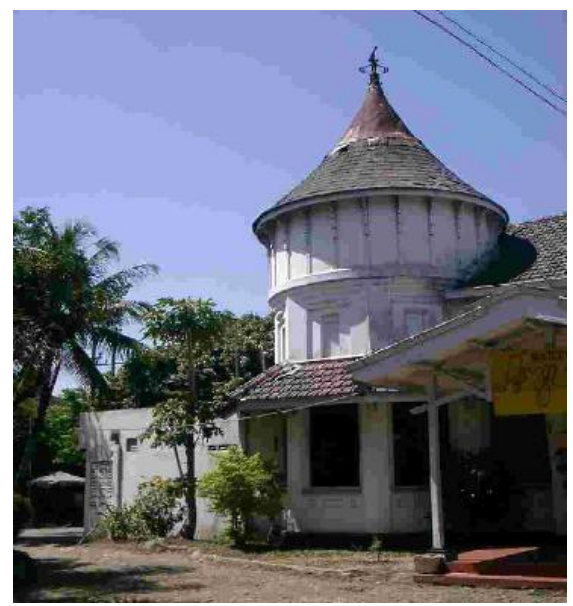

Figure 2. Building Jl. Arjuno no. 36 (2004) (Source: Antariksa, 2004)

The elements of roof, walls and floors the building

In the building corner the there is a circle geometric shape that forms a tube and cone building and there is a gable shape that has a basic geometric shape in the form of a triangle. The roof covering material in the cone-shaped part uses a shingle roof, while the saddleshaped part uses clay tile material. On a cone-shaped roof, the eaves of the roof are quite narrow, only about $30 \mathrm{~cm}$ and there are ornaments at the end of the roof. In addition two roofs, there is an eaves roof above the window that uses tile material as the cover. The eave above this window is quite wide.

The walls of the building use brick material with white paint finishing. There are rectangular window elements with wood and glass material. This building has a quite wide yard. This building consists of one floor.

\section{Current conditions (2015)}

Building on Jl. Arjuno no 36 at this time has changed the function of the residential function to a commercial function. The building functions as a cafe and supermarket currently. This causes changes in building facades that affect the visual quality of the area. 


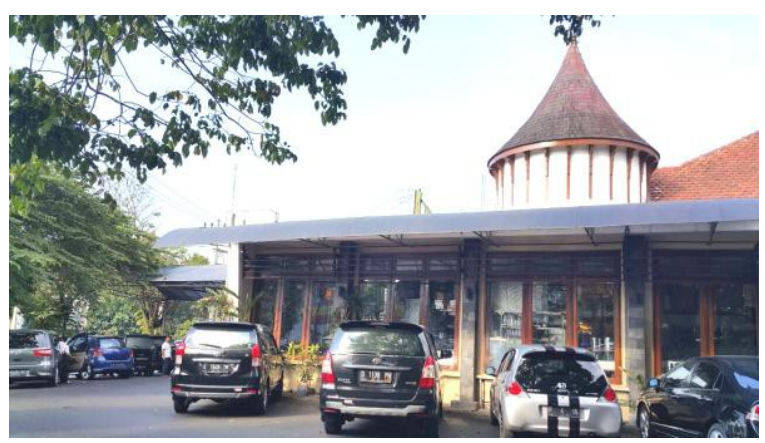

Figure 3. Building Jl. Arjuno no 36 west side (2015)

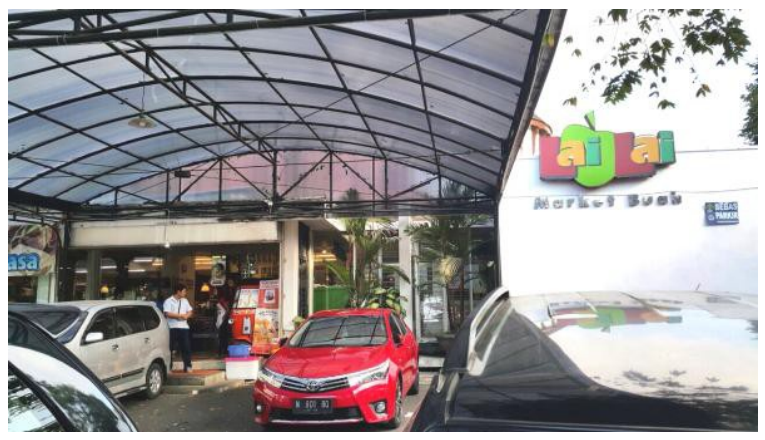

Figure 4. Building Jl. Arjuno no 36 north side (2015)

\section{The elements of roof, walls and floors the building}

Generally, the building main roof elements still have the same shape as the roof in 2004, namely a cone-shaped roof and have ornaments at the end of the roof. Roof cover material indicates that have been repairs from old conditions. Shingle and tile roofs have newer colours. The roof element at the top of the window is not found in buildings with this new function. It was replaced with a twin light roof that served as shade in the parking area of the building on the west and north sides of the building. There is a new material used, namely iron material.

The walls of the building changed significantly, following the new building functions. The building walls that were not too open, at this time are now quite open with the addition of window elements along the building walls. The windows and doors used from glass that give an open impression to the building.

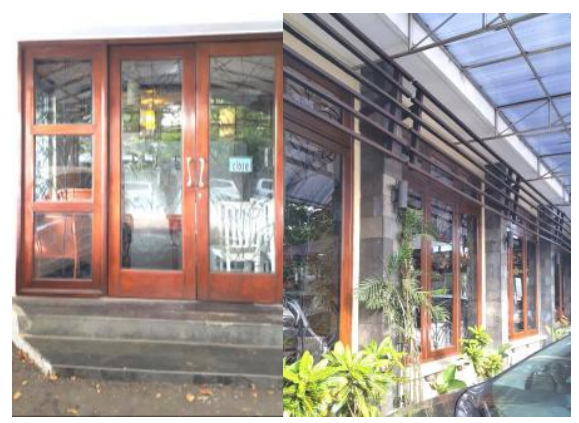

Figure 5. Door and Window Elements in Buildings

The height of the building has not changed, which still consists of one floor. When viewed from existing formations in 2004 and 2015, it shows a different visual character. In new buildings, colonial nuances are not visible because the walls are very changing and have an open impression. 


\section{The building of J1. Tanggamus no 23}

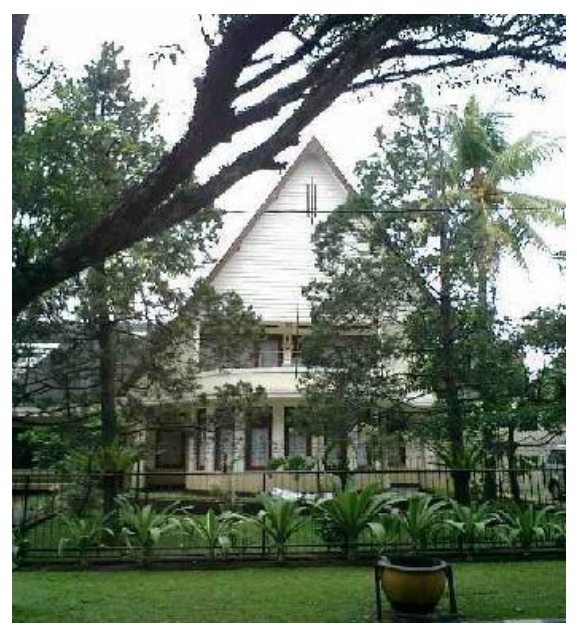

Figure 6. Building Jl. Tanggamus no 23 (2004) (Source: Antariksa, 2004)

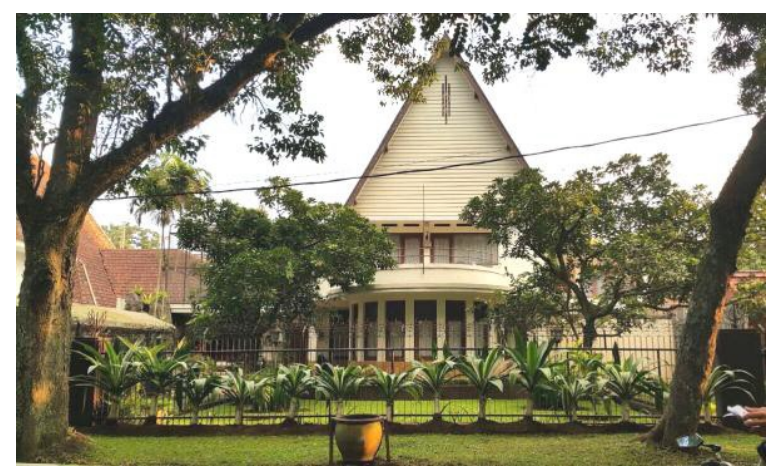

Figure 7. Building Jl. Tanggamus no 23 (2015)

This building is on the road to SMAK St. Albertus Malang and has a function as a residence. This building has a wide enough yard both outside and inside the fence. The building's fence is an iron fence that is quite low so that the building facade is quite visible even though there are some trees that block the visualization of building facades.

From the photos taken at different times in this building, it can be seen that building has not changed in the physical structure generally. Landscape elements that are on the front of buildings such as rows of plants outside the fence and trash cans are still the same as in 2004. Plant elements that change are inside the building fence, which uses different types of plants when viewed from the shape of the tree.

\section{The elements of roof, walls and floors the building}

The building roof has a saddle shape with a high angle, which is $>45^{\circ}$. It has a gevel on the front side that forms an isosceles triangle. The Gevel covered with wooden board material, painted in white and there are ornaments on the top. The roof shape with a steep angle intended to accelerate the rate of rain. It shows that this building has been built with a form that adapts to Indonesia's tropical climate. From the construction period, the building was built using a building style that developed around 1911-1942. 


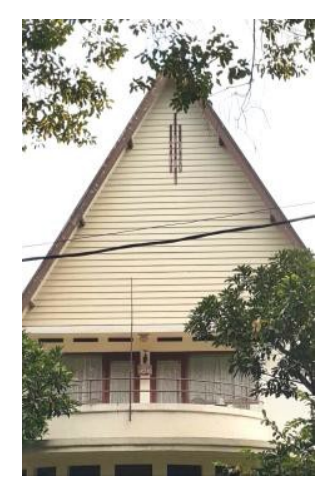

Figure 8. Gevel Roof on Buildings (2015)

The building wall element dominated by the window. The building walls are a curve and the windows arranged following the wall curved shape. The window element in the building has a rectangular shape with wood and glass material. The building's ventilation element is located at the top of the window on the second floor. When viewed from the front view, this building consists of two floors.

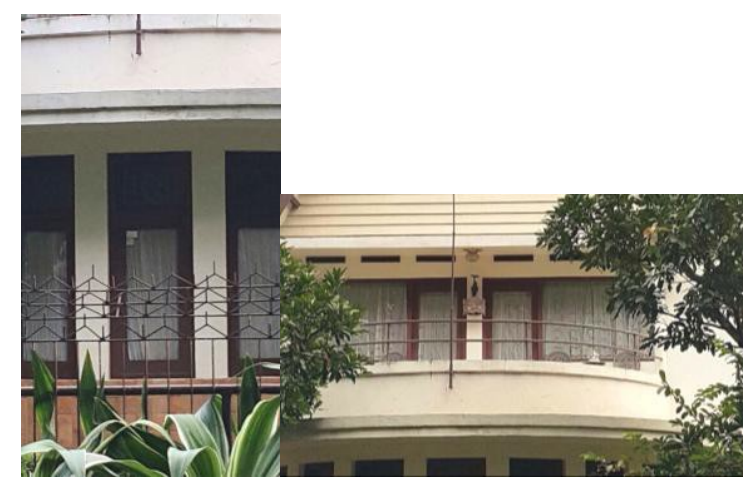

Figure 9. Window's element on Building (2015)

\section{The building of J1. Tenes no 14}

Tenes Street is on the west side of the Gajayana Stadium. Although not using a street name that comes from the mountain name, but the location of this street is still in the area of Gunung-Gunung Street. On this street, a building has a unique original design and forms a regional character (based on previous research). It has a function as a residence. This building has a low fence with a quite wide yard. Figure 10 shows the building shape in 2004.

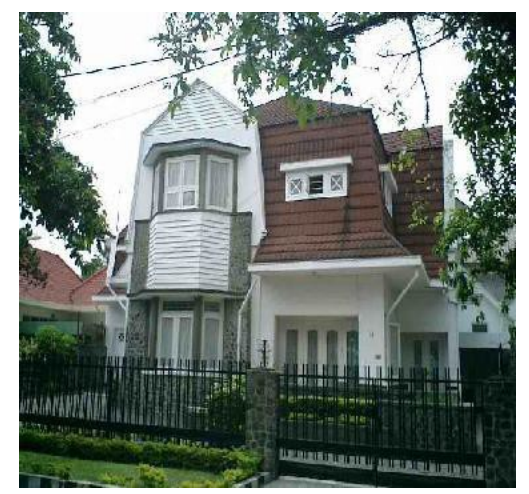

Figure 10. The building of Jl. Tenes no 14 (2004) (Source: Antariksa, 2004) 


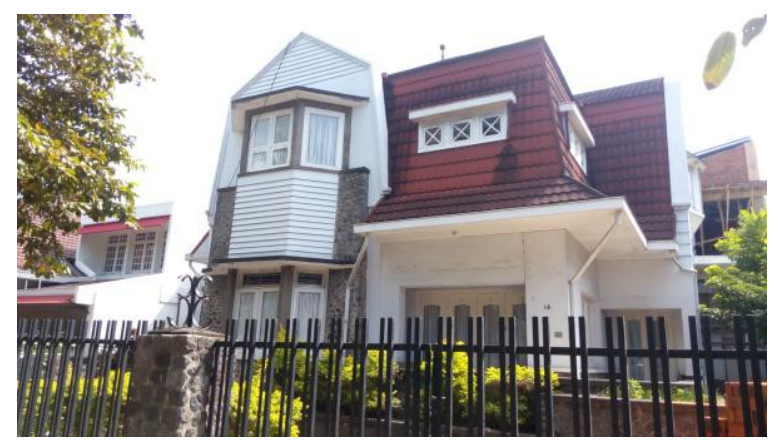

Figure 11. Building Jl. Tenes no 14 (2015)

\section{The elements of roof, walls and floors the building}

Generally, the building facade has not changed over a period of 11 years. This building consists of two floors with a unique shape on the roof elements. The roof of the building covers the walls of the second floor with roof covering material in the form of tile. At the front of the building, there is also a pentagon-shaped gevel with wood material painted white as a cover. There are window elements with white wooden frames and use glass material to put light into the building. The second-floor building walls covered with wood material that also uses white paint finishing. Roof eaves are not wide enough. In the part of the building that uses tile roof elements openings in the form of small windows/bovenleigh with a square shape. In the part of the building that uses tile roofs, the opening element is a small window/bovenleigh with a square shape.

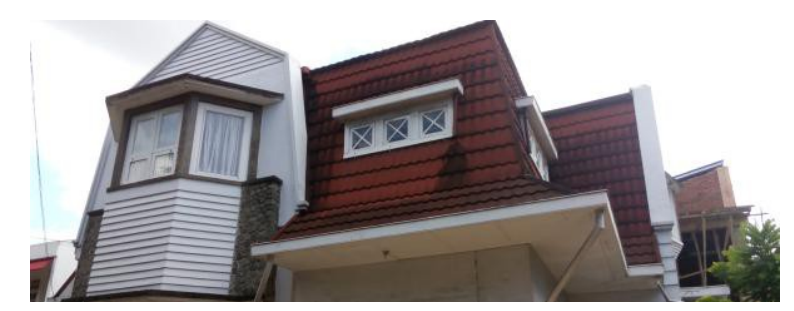

Figure 12. Roof, Wall and Building Openings on the second floor (2015)

On the first floor of the wall, it is dominated by openings in the form of doors and windows similar to the second floor, door and window elements on the first-floor use wooden frames painted white and use glass material.

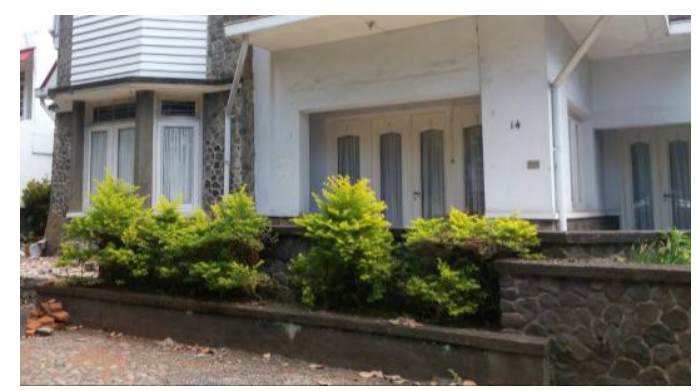

Figure 13. Wall and Openings Elements on the first floor (2015)

The changes that occur in the building are not significant, which is found on the left side in the form of additional space on the side. During the field survey, the construction was underway. 


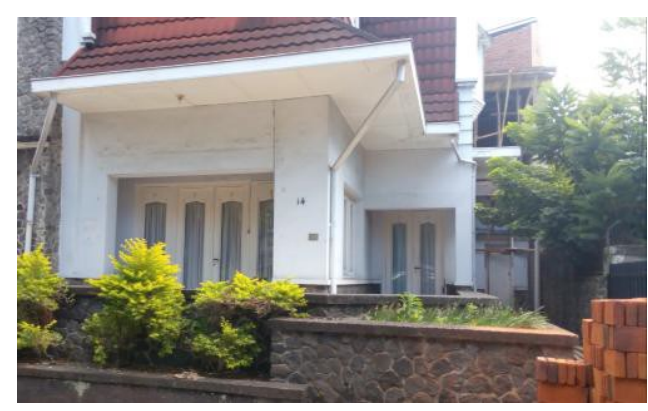

Figure 14. Changes to Buildings (2015)

\section{The building of Jl. Wilis no 27}

This building has a function as a residence with a high fence of about 1.5 meters and there are plant elements on the outside of the fence. The high fence makes the building facade less visible from outside.

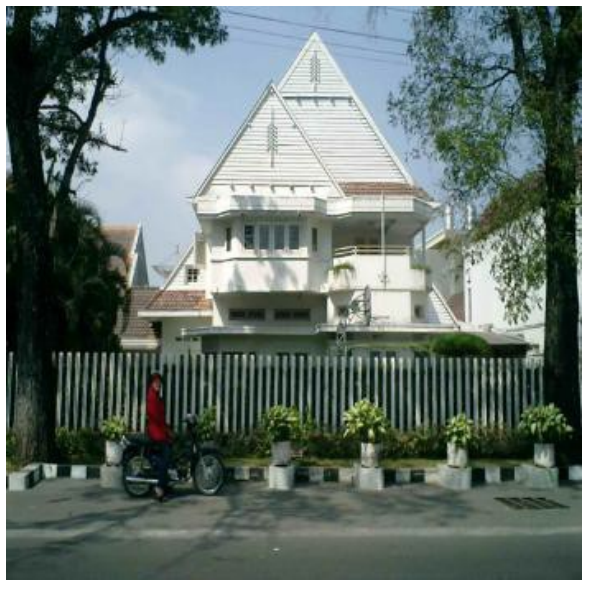

Figure 15. The building of Jl. Wilis no 27 (2004) (Source: Antariksa, 2004)

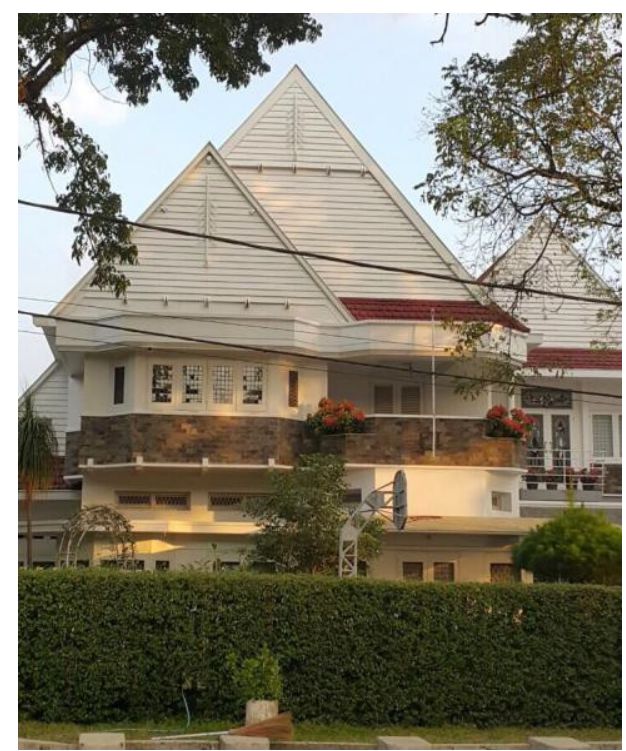

Figure 16. The building of Jl. Wilis no 27 (2015)

The element of roof, walls and floor the building

From images that show the building's condition in 2004 and 2015, generally, it can be seen that there is no change in the building physical structure so that the visual character of the 
building is maintained. The element that changes is the plant element that closes the front fence so that the building facade is increasingly invisible from outside the fence. This building consists of two floors. The roof is saddle-shaped with gevel on the front side. The building roof angle is quite steep, which is around $45^{\circ}$, like a house on Jl. Tanggamus no 23 . The building's gevel forms an equilateral triangle formation and consists of 3 gevel roofs on the front. The gevel is covered with white wood material with ornaments on rooftop. The shape of this fairly steep roof is an adaptation to Indonesia's tropical climate. The building was built using a building style that developed around 1911-1942 based on the construction period.

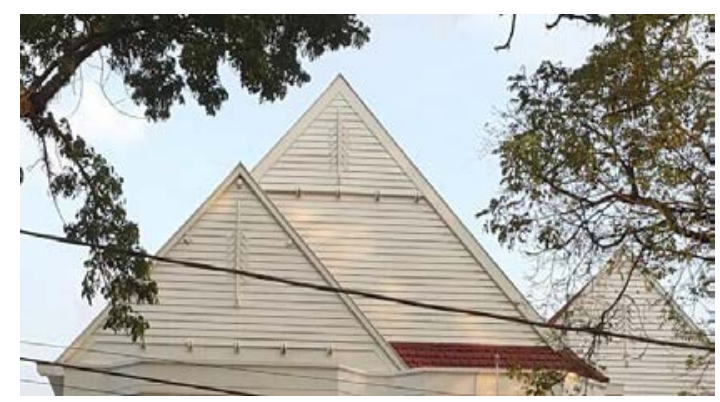

Figure 17. Gevel Roof on Buildings (2015)

The wall element on the second floor is dominated by a window. It uses brick material with a layer of natural stone on the wall located below the window. The window uses wood material painted white on the frame, and uses glass material. Glass used in windows on the second floor has a checkered motif.

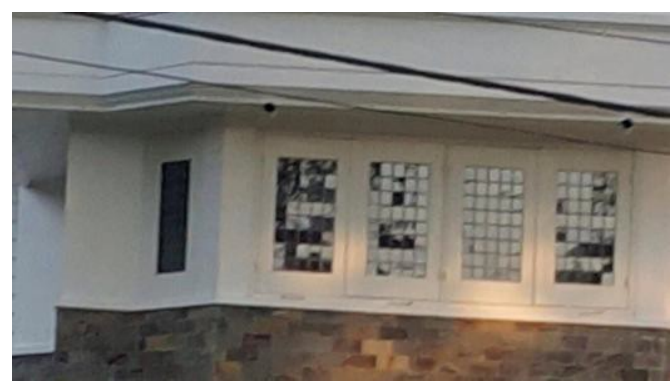

Figure 18. Window Elements on Second Floor (2015)

\section{The building of Jl. Rinjani no 17}

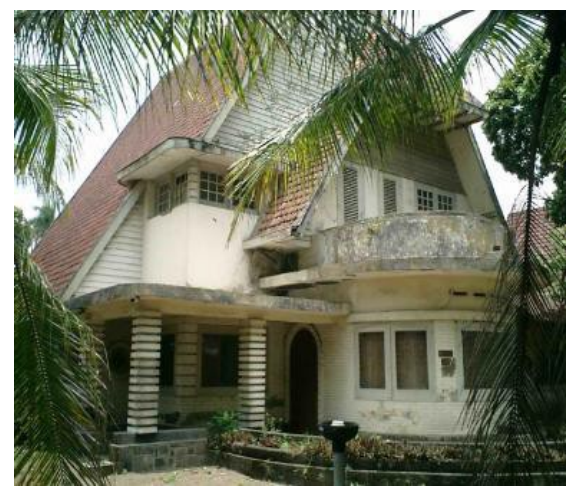

Figure 19. Building Jl. Rinjani no. 17 (2004) (Source: Antariksa, 2004) 


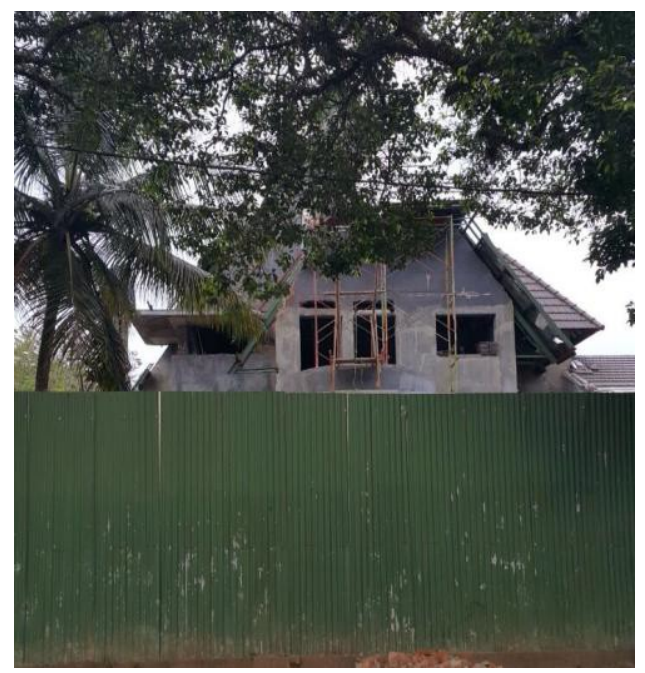

Figure 20. The building of Jl. Rinjani no 17 (2015)

During this study, the building on Jalan Rinjani no. 17 was under renovations. However, during field surveys, researchers were unable to see plans for new buildings because they were closed by zinc. However, when viewed from photos that were successfully obtained, it can be estimated that new building may have a shape that is identical to the old building. It can be seen in the roof shape and the shape of the opening at the top of the building.

\section{The element of roof, walls and floor the building}

The old building condition obtained from previous research shows that the building is poorly maintained and a little dirty because there is mould on the walls. In the old building, it can be seen that the building has a gable with a steep angle with a roof slope angle $\pm 45^{\circ}$. There is a curved shape on the front of the building like the shape found in the house Jl. Tanggamus no. 23. Window elements are also installed following the curved shape of the wall. This house consists of two floors with openings in the form of windows on the second floor. The building column has a square shape with a groove motif.

\section{The building of Jl. Buring no 2}

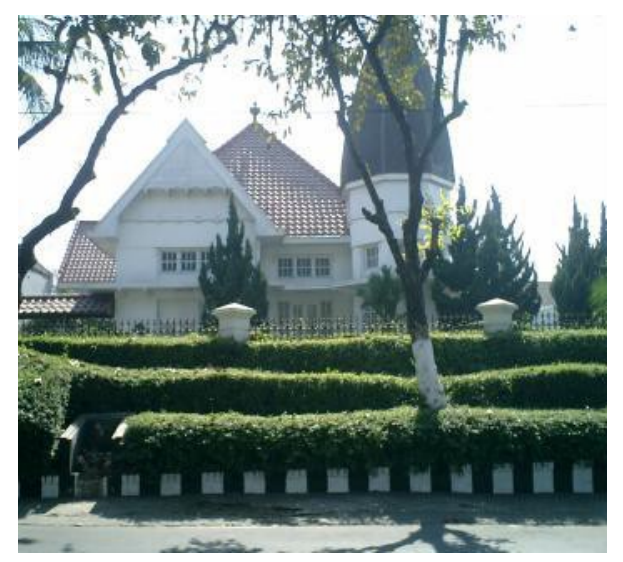

Figure 21. The building of Jl. Buring no 2 (2004) (Source: Antariksa, 2004) 


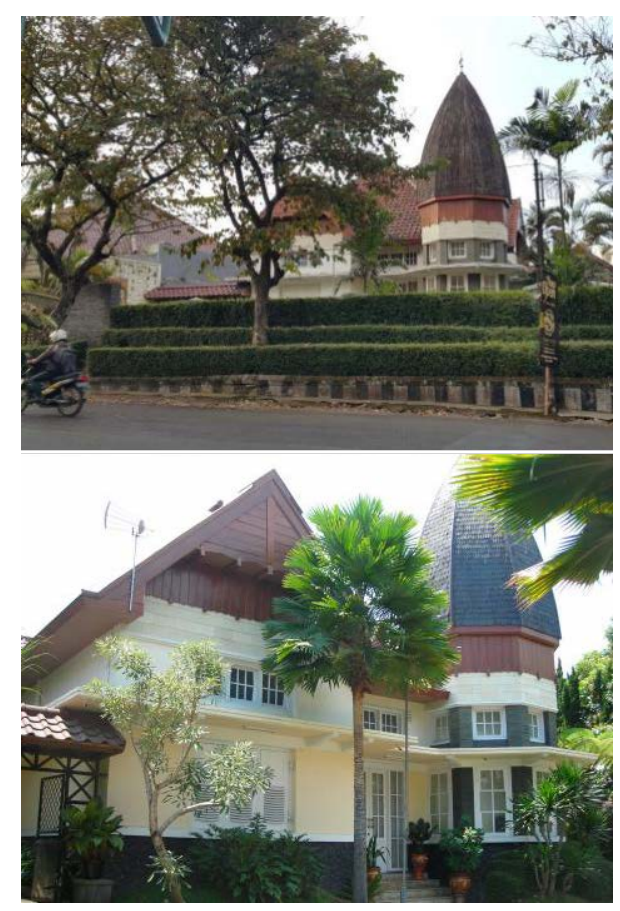

Figure 22. Bangunan Jl. Buring no 2 (2015)

This building has a function as a residence. In general, the building on Jalan Buring No. 2 has not changed in the physical structure. The fence elements in the form of hedgerows also did not change from 2004 to 2015. The changing visual elements are the colours in the gevel section and the upper wall element of the building.

\section{The element of roof walls and floor the building}

The roof element has three forms, there is cone, gable and shield roof. The cone- is in the corner of the building, while the gable with a steep angle is at the front of the building, and the shield roof is in the main part of the building. The roof cover material on the cone roof is in the form of shingles, while the gable roof uses a roof covering in the form of tile. The building's gevel element uses a cover with wooden board material arranged horizontally. In 2004, the element was white, while in 2015 the element was painted in accordance with the natural colour of wood material. These colour changes make changes to the visual character of the building.

The wall element is made of brick material with white paint finishing and there are parts covered with natural stone. There is a bovenleigh on the upper wall that is square with a white wooden frame and uses glass material. A window is rectangular, doors and windows use wood material with white paint finishing and use glass material.

\section{Conclusion}

From six buildings was analyzed, building facade elements can be grouped as follows: 
LOCAL WISDOM, Vol. 11 No. 2 July 2019

Local Wisdom Scientific Online Journal

Table 1. Typology of Building Facades

\begin{tabular}{clc}
\hline \multicolumn{1}{c}{ Tacades } & \multicolumn{1}{c}{ Types } & \multicolumn{1}{c}{ Location } \\
Element & & Buildings 1,6 \\
\hline Roof & Taper / cone roof & Buildings 2, \\
& Saddle with steep angles & $4,5,6$ \\
& Shield & Buildings 1,6 \\
& Gevel Roof & Buildings \\
& Shingle roof cover material & $2,3,4,5,6$ \\
& Roof tile cover material & Buildings 1,6 \\
& Brick material & Buildings 1-6 \\
Wall & Window elements with sills & Buildings 1,2 \\
& brown wood & Buildings \\
& Window elements with sills white & $3,4,5,6$ \\
& Wood & Buildings 1-6 \\
& Window with glass material & Buildings 1,6 \\
Total & 1 floor building & Buildings \\
& & $2,3,4,5$
\end{tabular}

\section{Source: Analysis Result}

From the analysis of building facade elements, 3 types of roofs were found, the use of gevel roofs was found in 4 buildings, roof cover material consisted of 2 types, wall elements in the entire building using brick material, wood frame colour consisting of 2 colours while building height of 2 types. In the building function element, 2 new functions are found, namely the commercial/trade function and the function of the residence.

In building morphology, there are two types of changes, there are:

1. Major changes occur in buildings no. 1 and 5.

2. Minor changes occur in buildings no. 3 and 6 .

\section{Ideas for Regional Development}

In accordance with the function at the beginning of its planning as a residential area, the buildings in the area of the Gunung-Gunung Street should maintain the function, because changes in function will $\mathrm{r}$ changes in the building visual character. In the physical form of the building, the direction of development/physical change should not change the basic form of the original building. Because changes in facade elements of the building will change the visual character of the building, as in the building on Jl. Arjuno No. 36 which originally functioned as a residence then switched functions to a commercial building. It is necessary to apply regulations and legal protection for ancient historic buildings in the study area by paying attention to the types and methods of protection, legal sanctions for violators, and subsidies for conservation/preservation bodies or individuals in the area. The preparation of building design guidelines is needed to clarify the preservation status of each building as well as the methods of preservation and utilization for each building.

\section{Reference}

Antariksa, Rusdi Tjahjono, S. T. (2004). Pelestarian dan Perlindungan Bangunan KunoBersejarah di Kawasan Jalan Gunung-Gunung Kota Malang. Jurnal ASPI (Asosiasi Sekolah Perencana Indonesia), 3(2), 107-123.

Antariksa. (2010). Tipologi Wajah Bangunan dan Riasan dalam Arsitektur Kolonial Belanda.

Ramadanta, A. (2010). Kajian Tipologi dalam Pembentukan Karakter Visual dan Struktur Kawasan (Studi kasus: Kawasan Ijen, Malang). Jurnal SMARTek, 8(2), 130-142. 
Typology and Morphology The Building in the Area of Gunung- Gunung Street Malang City Nur Ratih R.

Setyabudi, I., Antariksa, \& Murti Nugroho, A. (2012). Tipologi Dan Morfologi Arsitektur Rumah Jengki Di Kota Malang Dan Lawang. Arsitektur E-Journal, 5(1), 32-46.

Syahrozi. (2013). MORFOLOGI BENTUK TAMPAK (Studi Kasus Huma Gantung Buntoi). Jurnal Perspektif Arsitektur, 8(1). 